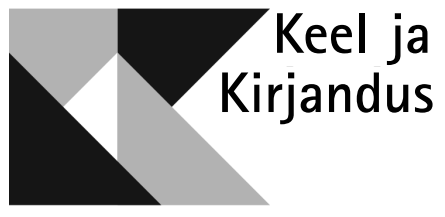

\title{
DIFTONGIDEST JA TRIFTONGIDEST EESTI KEELES KIHNU VOKAALISÜSTEEMI NÄITEL
}

HELEN TÜRK, EVA LIINA ASU, PÄRTEL LIPPUS, ELLEN NIIT

$\mathrm{K}$ äesolevas artiklis antakse ülevaade uurimusest, mis käsitleb mitme sihtväärtusega vokaalide ehk diftongide ja triftongide formantdünaamikat ning nende osiste jaotumist eesti keele vältesüsteemi seisukohalt. Töö tulemusi on varem esitatud ingliskeelses artiklis (Asu jt 2012) ja magistritöös (Türk 2013). Analüüsi jaoks on kasutatud Kihnu keelematerjali, aga uurimuse järeldusi võib laiendada eesti keelele üldisemalt. Kihnu murraku andmestiku kasutamise tingis eelkõige asjaolu, et Kihnu vokaalisüsteem on üks eesti keele rikkamaid; selles on säilinud täielik vokaalharmoonia, esineb ulatuslik pikkade vokaalide diftongistumine ning eesti vokaalisüsteemis haruldase nähtusena triftongid.

Artikli keskseks teemaks on diftongide osisvokaalide temporaalne jaotumine. Diftongi defineeritakse kui ühte silpi kuuluvat kahe kvaliteedilt erineva vokaalfoneemi järjendit (Catford 1977; Ladefoged 2006; Eek 2008). Diftongide puhul ei ole seega vokaalil ainult ühte identifitseerivat sihtväärtust nagu monoftongil, vaid kaks sihtmärki. Samas ei koosne diftong kahest päris omaette homogeensest häälikust, st häälikute piiril nende häälikute kvaliteet silmapilkselt ei muutu. Üleminekut ühe vokaali kvaliteedilt teisele nimetatakse siirdeks. 
Hoolimata diftongide rohkusest eesti keeles on neid suhteliselt vähe uuritud. Ilse Lehiste (1970) on võrdlevalt vaadelnud diftonge ja kahe vokaali järjendeid, mis tekivad sõnade piiril. Põhjalikuma ülevaate eesti keele diftongide kohta on andnud Hille Piir (1985), kes on analüüsinud diftonge akustiliselt ning esitanud nende segmenteerimisvõimalusi. Pire Teras on uurinud kirjakeele järgsilbi diftongide akustikat (Teras 1996) ja diftonge spontaankõnes (Teras 2012). Ülevaate eesti kirjakeele ja murdekõne diftongide foneetikast ja fonoloogiast annab oma raamatus Arvo Eek (2008: 122-151).

Peamiseks küsimuseks diftongide fonoloogia puhul on olnud see, kas diftong on mono- või bifoneemne üksus, ehk kas tegemist on kaksikvokaali või kahe vokaali järjendiga. Eesti keele diftongide kohta on Tiit-Rein Viitso (2008: 185) märkinud, et diftongid ei esinda iseseisvaid vokaalfoneeme, vaid foneemiühendeid ning on seega bifoneemsed üksused. Seda tõendavad asjaolud, et diftonge on eesti keeles palju ning nende esinemus eri väldetes ei ole süstemaatiline. Samuti võivad nad tihti tekkida morfofonoloogiliste protsesside tagajärjel. Lisaks sellele pole eesti keeles lühikesi diftonge, need ei saa esineda esmavältelise sõna rõhulises silbis. Diftongi mono- või bifoneemsuse üle võib otsustada selle järgi, kas teda saab osisteks segmenteerida. Osiste vahel oleva piiri leidmiseks on tavapärane vokaalidevaheline siire poolitada (nt Wiik 1965: 125). Kui diftongi osiste spektrite põhjal on võimalik määrata seda moodustavate vokaalide tüübid, võib diftongi pidada bifoneemseks (Eek 2008: 128). Nii Lehiste (1970) kui ka Piir (1985) on eesti keele diftongide kohta leidnud, et rõhulise silbi vastavate lühikeste monoftongide spektrid langevad peaaegu kokku diftongi moodustavate osisvokaalide spektritega.

Diftongid käituvad eesti keele vältesüsteemis üldjoontes nagu pikad vokaalid, kuid välte seisukohast on huvitav, kuidas on jaotatud diftongide komponendid teises ja kolmandas vältes. Lehiste (1970) on leidnud, et diftongi mõlema komponendi kestus on kolmandas vältes pikem kui teises vältes ehk kolmandas vältes pikenevad proportsionaalselt mõlemad osisvokaalid. Eegi (2008) järgi aga eristab teist ja kolmandat väldet diftongi teine vokaal, mille kestus kolmandas vältes pikeneb, esimest osist aga välde ei mõjuta ning see sarnaneb mõlemal juhul vastava lühikese vokaali kestusega. See on tema viimase vältekäsitluse oluliseks lähtekohaks (Eek, Meister 2003, 2004), kus CVVCV struktuuriga diftongi sisaldavates sõnades võrreldakse teise ja kolmanda välte puhul diftongi esimese komponendi ning järgsilbi vokaali suhet diftongi teise komponendiga. Käesoleva artikli eesmärgiks ongi uurida täpsemalt osisvokaalide jaotumist teise- ja kolmandavälteliste sõnade diftongides. Tuginedes Lehiste (1970) tulemustele, oleks ootuspärane, kui ka antud materjalis on kolmandas vältes diftongi mõlemad osisvokaalid pikemad kui teises vältes.

Uurimus põhineb Kihnu keelematerjalil. Kuna Kihnus on säilinud järjekindel vokaalharmoonia, siis esinevad sealses vokaalisüsteemis kõik üheksa eesti kirjakeele vokaali nii pearõhulises kui ka järgsilbis. Võrreldes teiste eesti murrakutega on pikad monoftongid Kihnus ulatuslikumalt diftongistunud, mis on olnud eelduseks triftongide tekkele. Analüüsiks valiti Kihnu hilisdiftongid $u a$, $i \ddot{a}, u \tilde{o}, \tilde{o} e$, $\ddot{u} e$, ie, mis on tekkinud pikkade madalate ja keskkõrgete monoftongide diftongistumise tulemusena (nt maa > mua, sä̈̈ski > siäski, 
kooli > kuõli, võõras > võeras, töö > tüe, keel > kiel). ${ }^{1}$ Võrreldes algupäraste $i$ - ja $u$-lõpuliste diftongidega, mis on kolmandas vältes üldiselt püsinud, aga kus teises vältes on diftongi teine komponent madaldunud või assimileerunud esimese komponendiga, on hilisdiftongid mõlemas vältes sama kvaliteediga (Lonn, Niit 2002: 23 jj).

Pikkade vokaalide diftongistumise juures on huvipakkuvad need diftongid, mis on moodustunud pika $a$ ja $o$ diftongistumise tagajärjel. Neid diftonge on murdetekstides kirja pandud mitmeti; nii esineb ua vastena sageli uä või $u a^{e}$ (nt puät, pua ${ }^{e}$ ) või oa (puadi poadi), pikale o-le vastav diftong uõ on

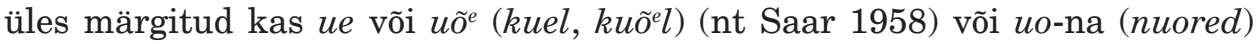
(Grigorjev jt 1997: 38). Esimesena kasutas ü̈-d Saareste (nt 1920: 25), mis võib tunduda mõneti üllatava valikuna, kuna sellist diftongi ei esine muudes eesti murretes (Pajusalu jt 2009: 133). Ilmselgelt ei ole lihtne otsustada hääliku täpse kvaliteedi üle vaid kuuldeliselt. Antud juhul on aga mitmete märgendusvariantide lisapõhjuseks Kihnu murrakus esinev metateetiline palatalisatsioon, kus esisilbi diftongile järgnevale konsonandile eelneb epenteetiline vokaal $e$ sõnades, mille teisest silbist on $i$ kadunud (Saar 1958; Eek 2008; Sang 2009). Tulemuseks on triftong. Kihnu fonoloogilises süsteemis on kaks triftongi: uae ja uõe (Sang 2009).

Võrdluseks diftongidele vaadeldakse selles artiklis ka Kihnu monoftongide kvaliteeti ja kestusi kõigis kolmes vältes ning triftongide kvaliteeti ja kestust ning osiste kestusi.

\section{Kõnematerjal ja meetod}

Testsõnadeks valiti kahesilbilised nimisõnad, kus uuritavad diftongid (i $\ddot{a}, u a$, $\tilde{o} e, u \tilde{o}, i e, \ddot{u} e$ ) ja monoftongid ( $a, \ddot{a}, o, \tilde{o}, e, \ddot{o}, u, i, \ddot{u})$ asusid esimeses, pearõhulises silbis. Kuna triftongid saavad Kihnu murrakus esineda vaid ühesilbilistes sõnades, olid kõik triftongidega (uae, uõe) testsõnad ühesilbilised ja seega kolmandas vältes. Monoftongidega sõnad esinesid materjalis kõigis kolmes vältes, diftongidega teises ja kolmandas vältes. Kokku oli materjalis 102 testsõna. Testsõnadega moodustati lauseid, kus sama sõna paigutati nii lausealgulisse kui ka -lõpulisse positsiooni. Järgmised laused näitlikustavad monoftongiga esma-, teise- ja kolmandavältelisi, diftongiga teise- ja kolmandavältelisi ja triftongiga kolmandavältelisi testsõnu:

Kodo oli pere. Pere oli kodo. (Kodus oli pere. Pere oli kodus.)

Mõõgad olid üel. Üel olid mõ̃̃gad. (Mõõgad olid vööl. Vööl olid mõõgad.)

Praami tuli uõta. Isä uõtas praami. (Praami tuli oodata. Isa ootas praami.)

Siened olid metses. Metses olid siened. (Seened olid metsas. Metsas olid seened.)

Kuõli läksid poesid. Poesid läksid kuõli. (Kooli läksid poisid. Poisid läksid kooli.)

$\boldsymbol{R u a}^{\mathrm{e} v}$ oli põllal. Põllal oli rua ve. (Kraav oli põllul. Põllul oli kraav.)

${ }^{1}$ Muutusele ei ole allunud pikad kõrged vokaalid $i$, $\ddot{u}$ ja $u$ (Saar, Valmet 1997: 36) ning hoolimata laiaulatuslikust diftongistumisest võivad teatud sõnades ja sõnavormides esineda pikad madalad ja keskkõrged monoftongid, seda eriti uuemates ja laensõnades. Mõnel juhul on ka pikk ö või õ võinud püsima jääda, nagu sõnades pöök, rõõsk, põõsas (Saar 1958). 
Materjal lindistati Kihnu saarel 2011. ja 2012. aasta suvel välitööde käigus, kasutades Edirol R-09HR diktofoni. ${ }^{2}$ Keelejuhtidel paluti lugeda testsõnadega lauseid sedelitelt, kus igale sedelile oli trükitud ainult üks lause. Laused loeti juhuslikus järjekorras, iga lause esines korra. Keelejuhte oli kokku 13 (sh 6 naist ja 7 meest) ja nad olid lindistamise ajal vanuses 19-52 (keskmine vanus 36). Kõik keelejuhid olid sündinud Kihnus ja suurema osa oma elust ka saarel elanud.

Analüüsis ei olnud võimalik kasutada kogu lindistatud materjali; välja tuli jätta sellised sõnad, mis olid hääldatud venitades, kirjakeelselt, liiga vaikselt või mille taustal oli müra. Analüüsitud materjali jaotumine väldete kaupa on esitatud tabelis 1 .

Tabel 1 .

\section{Analüüsitud monoftongide, diftongide ja triftongide arv esimeses (Q1), teises (Q2) ja kolmandas (Q3) vältes}

\begin{tabular}{|l|c|c|c|c|}
\hline Tüüp & Q1 & Q2 & Q3 & Kokku \\
\hline Monoftong & 369 & 252 & 200 & 821 \\
\hline Diftong & & 294 & 362 & 656 \\
\hline Triftong & & & 121 & 121 \\
\hline Kokku & 369 & 546 & 683 & 1598 \\
\hline
\end{tabular}

Materjali analüüsimisel kasutati vabavaralist kõneanalüüsiprogrammi Praat (Boersma, Weenink 2015). Mõõdeti lühikeste ja pikkade monoftongide, diftongide ja triftongide kahe esimese formandi väärtusi (F1 ja F2), mitme sihtväärtusega vokaalide (diftongide ja triftongide) puhul nende osiste kestusi ja diftongidel lisaks ka osisvokaalide vahele jäävate siirete kestusi.

Vokaalide formantväärtuste mõõtmisel kasutati formantdünaamika meetodit, mis on leidnud laialdast kasutust nii eri kõnelejate kui ka eri murrete vokaalide võrdlustes (nt Greisbach jt 1995; McDougall 2006; McDougall, Nolan 2007; Jacewicz jt 2011) ning mida on eriti oluliseks peetud diftongide analüüsi juures, kuna neid häälikuid iseloomustab kahte sihtväärtust ühendav trajektoor (Holbrook, Fairbanks 1962; Harrington, Cassidy 1994; Watson, Harrington 1999). Kui traditsiooniliselt on mõõdetud formantide väärtust ainult ühest punktist vokaali stabiilse osa keskelt, siis formantdünaamika meetodi järgi mõõdetakse formandisagedusi mitmes üksteisest võrdsel kaugusel olevas punktis kogu vokaali kestuse jooksul. Sellise analüüsimeetodi tulemuseks on vokaali formantväärtuste trajektoor, mis võimaldab jälgida vokaali kvaliteedi muutumist vokaali kestel.

Analüüsi käigus märgiti kõigepealt käsitsi vokaalide piirid. Seejärel kasutati Praati skripti, et arvutada iga vokaali kogukestus ja jagada see kümneks võrdseks osaks. Formantväärtused leiti samuti Praati skriptiga ning sellele järgneva käsitsi kontrolli käigus kõrvaldati võimalikud automaatanalüüsist tulenevad vead. Seega saadi mõlema formandi jaoks kontuurid, mis koosnesid üheksast väärtusest.

\footnotetext{
${ }^{2}$ Materjal on hoiul TÜ eesti murrete ja sugulaskeelte arhiivis (http://www.murre.ut.ee/ arhiiv/).
} 
Diftongide puhul mõõdeti nende komponentide ja komponentidevaheliste siirete kestusi. Selleks segmenteeriti iga diftong kolmeks osaks, toetudes diftongi spektrile, mis koosneb kahest enam-vähem stabiilsest osast ja ülemineku- ehk siirdefaasist, kus diftongi esimese komponendi formandid liiguvad teise komponendi formantide suunas. Siirde alguse ja lõpu piir märgiti sinna, kus oli näha kõige suuremat formandiliikumist (vt joonist 1). Triftongide puhul oli siirdealasid keerulisem määratleda ja seepärast siirdeid eraldi ei märgendatud. Iga triftong jaotati kuuldelise ja spektraalinfo põhjal kolmeks osistevaheliste siirete keskel.

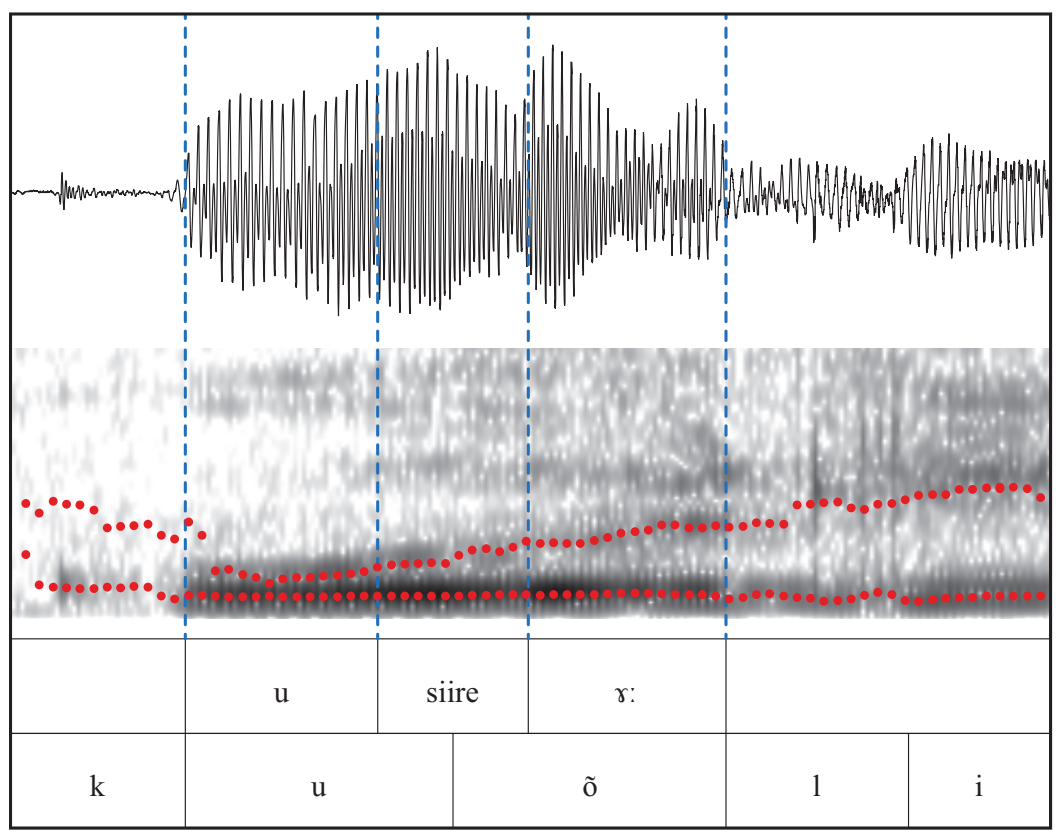

J o o n i s 1. Ostsillogramm ja spektrogramm sõnast kuõli, kus on näha diftongi jaotamine kolmeks osaks: esimeseks ja teiseks osiseks ja nendevaheliseks siirdeks. Joonisel on punktiirjoonega tähistatud esimese kahe formandi (F1 ja F2) kontuurid.

Diftongide ja triftongide puhul arvutati iga vokaaliosa pikkus (ingl Vowel Section Length, lühendatult VSL) ehk vokaali formanttrajektooris kõrvutiste mõõtmispunktide vaheline formantväärtuste eukleidiline kaugus barkides. Sama metoodikat on kasutanud ning täpsemalt kirjeldanud Jacewicz jt (2011) ja Asu jt (2012). Käsitsi märgitud osistevahelisi piire diftongides ja triftongides võrreldi automaatselt leitud punktiga, kus vokaali kvaliteedi muutus on formanttrajektooris kõige suurem.

Edasine andmetöötlus viidi läbi programmiga R (vt R Core Team 2013). Häälikukestuste välteerinevuste testimiseks kasutati lineaarset segamudelit, arvestades keelejuhi ja testsõna mõju kui juhusliku faktoriga. 


\section{Tulemused}

\subsection{Vokaalide formantdünaamika}

Joonisel 2 on näha kõigi keelejuhtide keskmistatud vokaalide paiknemine vokaaliruumis, mis on visandatud monoftongide keskmiste väärtuste põhjal. Iga keelejuhi formantide väärtused on normaliseeritud z-skoorideks, mis kujutavad formantväärtusi standardhälbena keskväärtusest. Selline normaliseerimisprotseduur lubab vältida kõnetrakti kujust tingitud erinevusi mees- ja naiskõnelejate vahel ning võimaldab kirjeldada vokaalide paiknemist üksteise suhtes vokaalisüsteemi piires. Joonisel vastab vertikaaltelg F1 väärtusega kirjeldatud häälduskoha kõrgusele ning horisontaaltelg F2 väärtusega kirjeldatud ees-tagapoolsusele. Normaliseerimise tagajärjel puudub küll formantväärtustel akustilistele mõõtmistele vastav mõõtühik, kuid see ei olegi antud juhul niivõrd oluline, sest eesmärk on visualiseerida formantväärtuste muutumist vokaali jooksul.

Nii tuleb esile erinevus ühe ja mitme sihtväärtusega vokaalide vahel: monoftongide vokaali kvaliteet kõigub ainult vähesel määral oma sihtväärtuste ümbruses ja seepärast on monoftongide formanttrajektoorid väga lühikesed. Diftongide ja triftongide puhul saab aga jälgida formantväärtuste muutumist ühe vokaali sihtväärtuste lähedusest teise (ning kolmanda) vokaali sihtväärtuste suunas ja formanttrajektooridel on selge suund ühest sihtmärgist teise, mis küll alati ei ühti monoftongi sama sihtväärtusega. Triftongide trajektoorid on kõige pikemad ja liikumine on kerge kaarega, ühendades kõiki kolme sihtmärki.

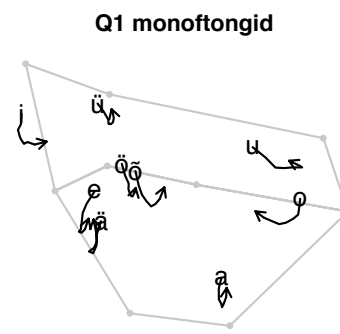

Q3 triftongid

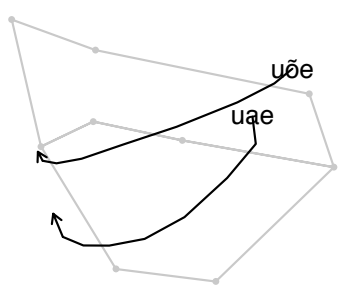

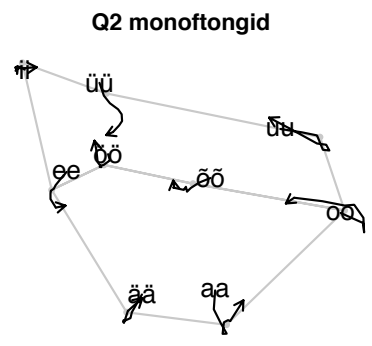

Q2 diftongid

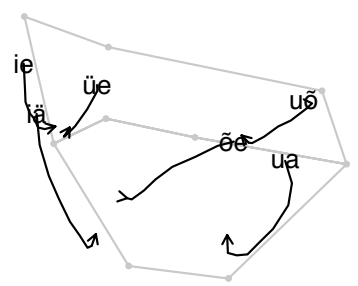

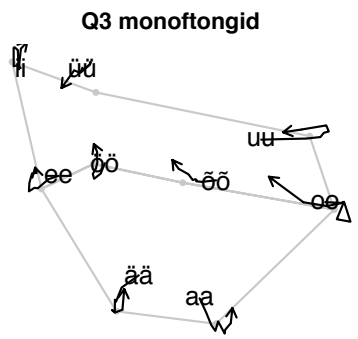

Q3 diftongid

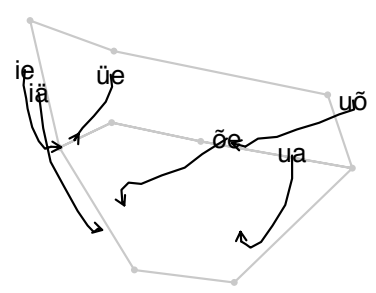

J o o n is 2. Kihnu monoftongide (Q1, Q2, Q3), diftongide (Q2, Q3) ja triftongide (Q3) formanttrajektoorid vokaalidiagrammidel. 
Monoftongide paigutuse osas ei ole Kihnus märkimisväärseid erinevusi eesti vokaalisüsteemi varasemate kirjeldustega (vrd Eek, Meister 1994; Lippus jt 2013). Ka siin on näha üldine tendents, et lühikesed vokaalid on võrreldes pikkade vokaalidega kesksemad ehk nihkunud akustilises ruumis keskvokaalide suunas ja pikad monoftongid teise- ja kolmandavältelistes sõnades ei erine kvaliteedilt üksteisest. Kõige silmatorkavam Kihnu vokaalide kvaliteedierinevus on kindlasti lühikese /õ/ ja /ö/ kokkulangemine. Kihnu ja kirjakeele vokaalisüsteemi peamiseks erinevuseks on vokaalide /ä/ ja /i/ kvaliteet: Kihnu /ä/ on kinnisem ehk /e/-poolsem esma- ja kolmandavältelistes sõnades ja Kihnu pikk/i/ on tagapoolsem kui kirjakeelne. Täpsema Kihnu ja kirjakeele monoftongide võrdluse on esitanud Asu jt (2012).

\subsection{Vokaaliosa pikkus}

Joonis 3 võrdleb diftongide käsitsi leitud osiseid automaatselt leitud VSL-kontuuridega, kus vokaali kvaliteedi muutumist vokaali jooksul väljendab kõrvutiste mõotmispunktide vaheline eukleidiline kaugus. See võimaldab kahe mitmemõõtmelises ruumis (F1 ja F2) registreeritud punkti vahelist otsekaugust väljendada ühemõõtmelise suurusena. Kui diftongid ja triftongid sisaldavad osisvokaalidele vastavaid stabiilseid osi, kus formantväärtused muutuvad vähe, ja neid ühendavaid siirdefaase, mille jooksul toimuvad kiiremad muutused vokaali kvaliteedis, siis võiks eeldada, et selline stabiilsemate ja dünaamiliste osiste jaotus peaks kajastuma ka VSL-kontuuris.
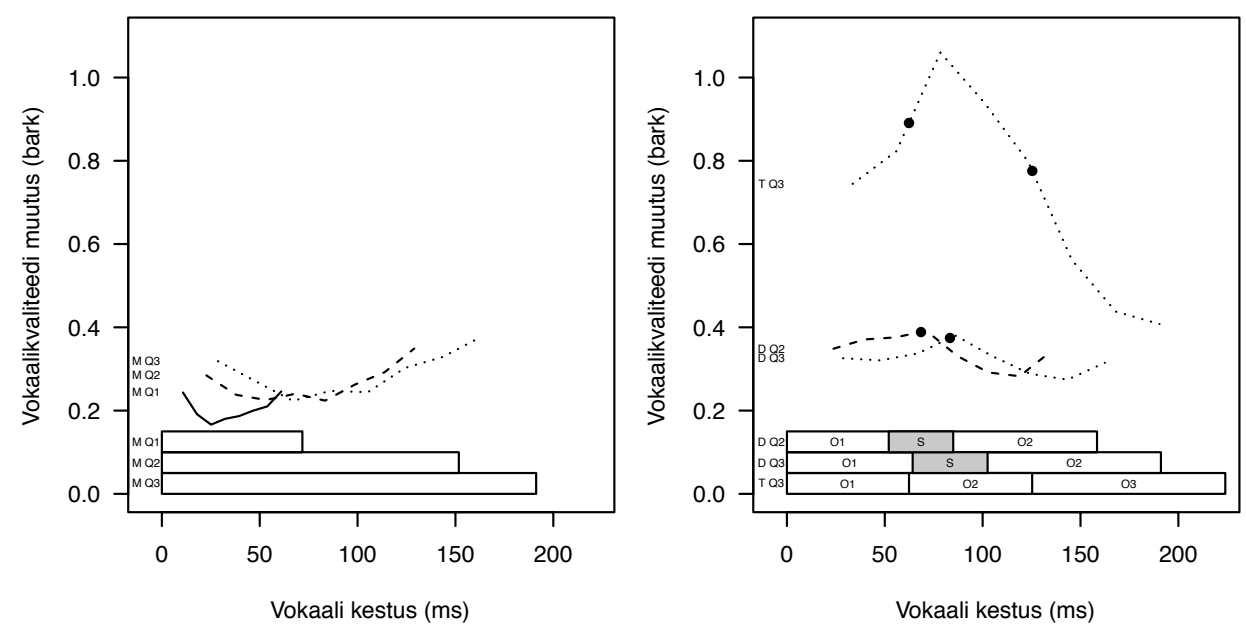

Joonis 3. Vokaalide kestus ja VSL-kontuurid. Vasakul monoftongid (M), paremal diftongid (D) ja triftongid (T), nende käsitsi leitud osiste kestused kastdiagrammina (O1 - esimene osis, O2 - teine osis, O3 - kolmas osis, S - siire). Joontega on kujutatud vokaali kvaliteedi muutus eukleidilise kaugusena kõrvutiste mõõtmispunktide vahel (Q1 - pidev joon, Q2 - katkendjoon, Q3 - punktiirjoon) ning punktiga on tähistatud osistevahelised käsitsi leitud piirid. 
Kogukestuse poolest eristuvad monoftongidel kolm väldet $\left[\chi^{2}(\mathrm{df}=2, \mathrm{~N}=\right.$ $757)=97,8 ; \mathrm{p}<0,001]: \mathrm{Q} 1$ - $72 \mathrm{~ms}, \mathrm{Q} 2$ - $154 \mathrm{~ms}$ ja Q3 - $184 \mathrm{~ms}$. Diftongid, mida esmavältelistes sõnades ei saa esineda, ei erine teises ja kolmandas vältes kogukestuse poolest monoftongidest. Küll aga on kõigist teistest selgelt pikemad triftongid (keskmiselt $222 \mathrm{~ms}$ ). Samas pole triftongid välte poolest monoftongide ja diftongidega otseselt võrreldavad, kuna esinevad vaid ühesilbilistes sõnades.

Joonise 3 vasakpoolsel paneelil on kujutatud vokaalide kvaliteedi muutus monoftongides. Kvaliteedi muutused on suuremad vokaali alguses ja lõpus, kus paiknevad siirded vastavalt eelnevalt konsonandilt ja järgnevale konsonandile. Kuigi kvaliteedi muutused pole vokaali keskel päris olematud, on need siiski monoftongi keskosas kõige väiksemad. Seevastu diftongidel ja triftongidel (vt joonise 3 parempoolset paneeli) muutub vokaali kvaliteet kõige rohkem just vokaali keskosas. Diftongide ja eriti triftongide VSL-kontuurist on aga raske leida sellist osa, kus kvaliteedimuutus oleks väga väike ja mida võiks selgepiiriliselt ühe või teise sihtvokaali stabiilseks osiseks pidada.

VSL-kontuure vaadates selgub, et diftongidel langeb käsitsi leitud osisvokaalide vaheline piir (ehk siirde keskpunkt) kokku punktiga, kus vokaali kvaliteet kõige rohkem muutub. Nagu näha jooniselt 3, ei ole triftongi käsitsi leitud osiste piiridel aga selget seost vokaali kvaliteedi muutumisega ja vokaali kvaliteedi muutumise kõver ei viita otseselt kolmele eristuvale osisele. Sarnaselt diftongidega on triftongidel samuti vaid üks märgatav üleminekufaas ühelt vokaalilt teisele, mitte kaks VSL-kontuuri tippu, mis märgiksid kahte siirdefaasi. Sellest võib järeldada, et käsitsi leitud osiste piirid ei lange triftongide puhul kokku suuremate muutustega vokaali kvaliteedis. Põhjuseks, miks triftongide VSL-kontuuris ei ole kahte tippu, võib olla see, et üleminek esimeselt osiselt teisele on järsk, kuid edasi liiguvad F2 väärtused kogu teise vokaali jooksul tõusvas joones ning üleminek kolmandale vokaalile toimub suhteliselt sujuvalt.

Joonisel 4 on näidatud diftongi osiste kestused. Joonise vasakpoolsel paneelil on näha, et absoluutkestuste poolest on diftongi mõlemad osised pikemad kolmandas vältes: esimene osis Q2 - $50 \mathrm{~ms}$ vs. Q3 - $62 \mathrm{~ms}\left[\chi^{2}(\mathrm{df}=1\right.$, $\mathrm{N}=243)=48,6 ; \mathrm{p}<0,001]$ ja teine osis $\mathrm{Q} 2-72 \mathrm{~ms} v s . \mathrm{Q} 3-86 \mathrm{~ms}\left[\chi^{2}(\mathrm{df}=1\right.$, $\mathrm{N}=243)=43,3 ; \mathrm{p}<0,001]$. Selline tulemus on igati ootuspärane ning kinnitab Lehiste (1970) tulemusi. Jooniselt on näha, et ka osistevaheline siire on kolmandas vältes pikem: Q2 - $31 \mathrm{~ms}$ vs. Q3 - $37 \mathrm{~ms}\left[\chi^{2}(\mathrm{df}=1, \mathrm{~N}=243)=32,1\right.$; $\mathrm{p}<0,001]$. Seega, kolmandas vältes on sarnaselt monoftongidega kogu diftong pikem kui teises vältes. Joonise 4 paremal paneelil on osiste kestused väljendatud protsendina diftongi kogukestusest. Selgub, et proportsionaalselt ei ole osiste kestusel välteti statistiliselt olulist erinevust: esimese osise kestus on $33 \%$, siirde kestus $21 \%$ ning teise osise kestus $46 \%$ kogu diftongi kestusest.

Triftongi osiste mõõtmistulemused näitasid, et triftongi kogukestusest moodustavad esimene ja teine vokaal keskmiselt sama suure osa (ligikaudu $28 \%$ ). Märkimisväärselt pikem on kolmas vokaal, mis on keskmiselt $44 \%$ kogu triftongi kestusest. Võrreldes diftongidega on triftongi esimene osis veidi lühem, kuid kolmanda osise kestus on sarnane diftongi teise vokaali kestusega. 

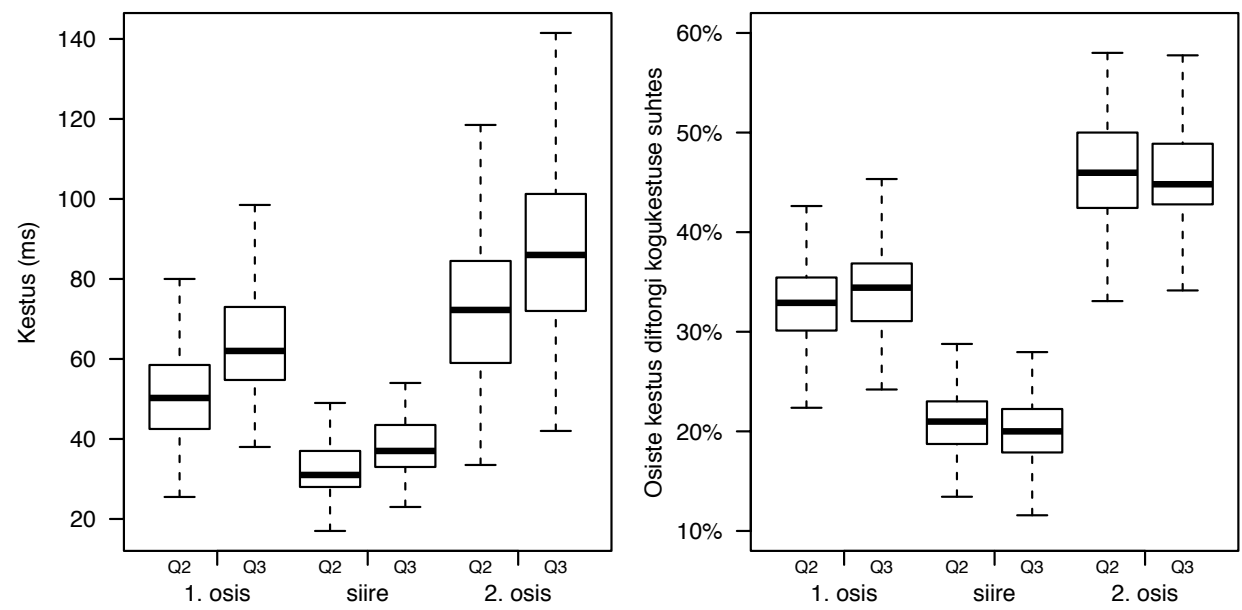

J o o n i s 4. Diftongi osiste kestused teise- ja kolmandavältelistes sõnades. Vasakpoolsel paneelil osiste kestused millisekundites ja paremal osiste kestused protsendina diftongi kogukestusest.

\section{Kokkuvõte}

Artikli peamiseks eesmärgiks oli uurida vokaalosiste jaotumist teise- ja kolmandavältelistes diftongides. Lisaks uuriti triftongide temporaalseid omadusi ning monoftongide, diftongide ja triftongide kvaliteeti. Materjalina kasutati Kihnu murraku loetud lauseid. Mõõdeti monoftongide, diftongide ja triftongide üldkestusi ning viimase kahe osisvokaalide kestust. Diftongide puhul mõõdeti ka osistevaheliste üleminekute ehk siirete kestust. Osistevahelised piirid märgendati käsitsi ning neid võrreldi automaatselt leitud punktiga, kus vokaali kvaliteedi muutus on kõige suurem.

Vokaalide kvaliteedi uurimiseks kasutati formantdünaamika meetodit, mis võimaldab näha kvaliteedi muutumist kogu vokaali kestel. Monoftongide formanttrajektoorid olid väga lühikesed, sest üksikvokaali kvaliteet kõigub ainult vähesel määral oma sihtväärtuste ümbruses. Diftongide ja triftongide formanttrajektooridel oli aga kindel suund ühest sihist teise. Kõige pikemad olid triftongide trajektoorid, ühendades kõiki kolme sihtmärki. Tulemused näitasid, et ka Kihnu materjalis on lühikesed vokaalid võrreldes pikkade vokaalidega kesksemad ja pikad monoftongid teise- ja kolmandavältelistes sõnades ei erine üksteisest kvaliteedi poolest. Kihnu vokaalides hakkas silma lühikese /õ/ ja /ö/ kokkulangemine.

Diftongide keskmisi kogukestusi kõrvutati pikkade monoftongide omadega ning leiti, et need osutusid sarnaseks, käitudes ka välteti ühtmoodi: kolmandas vältes on nii diftongid kui ka monoftongid pikemad kui teises vältes. Kõigist pikemad olid triftongid.

Üldiselt on diftongi esimene osis lühem kui teine. Vokaalidevaheline siirdefaas moodustas diftongi üldkestusest küllaltki suure osa, $21 \%$. Võrreldes aga osiste kestusi välteti, selgus, et absoluutkestuste poolest on diftongi mõlemad 
osised pikemad kolmandas vältes ning proportsionaalselt ei ole osiste kestusel välteti statistiliselt olulist erinevust. See tulemus on kooskõlas Lehiste (1970) tähelepanekutega, kuid vastuolus Eegi (2008) omadega, millele Eek on üles ehitanud ka oma viimase vältekäsitluse (Eek, Meister 2003, 2004).

Triftongide osisteks jagamisel ilmnes, et esimene ja teine vokaal on enamvähem võrdse pikkusega, olles aga kolmandast märkimisväärselt lühemad. Triftongide spektri põhjal saab öelda, et kõige kiiremini toimuvad muutused üleminekul esimeselt osiselt teisele, kolmandale osisele liikudes muutuvad formandid sujuvalt, mistõttu ei ole siirdefaasi võimalik eristada.

Uurimus on valminud Eesti Teadusagentuuri projekti IUT2-37 „Soome-ugri keelte prosoodiline struktuur ja keelekontaktid" raames.

\section{Kirjandus}

As u, Eva Liina, Lippus, Pärtel, Niit, Ellen, Türk, Helen 2012. The acoustic characteristics of monophthongs and diphthongs in the Kihnu variety of Estonian. - Linguistica Uralica, kd XLVIII, nr 3, lk 161-170.

Boersma, Paul, Weenink, David 2015. Praat: Doing phonetics by computer [Arvutiprogramm].

C atford, John Cunnison 1977. Fundamental Problems in Phonetics. Edinburgh: Edinburgh University Press.

Eek, Arvo 2008. Eesti keele foneetika I. Tallinna Tehnikaülikooli Küberneetika Instituut. Tallinn: TTÜ Kirjastus.

E ek, Arvo, M e is te r, Einar 1994. Eesti vokaalide sihtväärtused hääldus- ja tajuruumis. - Keel ja Kirjandus, nr 7, lk 404-413; nr 8, lk 476-483; nr 9, lk 548-553.

E ek, Arvo, M e i st e r, Einar 2003. Foneetilisi katseid ja arutlusi kvantiteedi alalt (I). Häälikukestusi muutvad kontekstid ja välde. - Keel ja Kirjandus, nr 11, lk 815-837; nr 12, lk 904-918.

E ek, Arvo, Meis te r, Einar 2004. Foneetilisi katseid ja arutlusi kvantiteedi alalt (II). Takt, silp ja välde. - Keel ja Kirjandus, nr 4, lk 251-271; nr 5, lk 336-357.

Greis bach, R., Esser, O., Weinst ock, C. 1995. Speaker identification by formant contours. - Studies in Forensic Phonetics: BEIPHOL 64. Toim A. Braun, J-P. Köster. Trier: Wissenschaftlicher Verlag Trier, lk 49-55.

Grigorjev, Piret, Keevallik, Leelo, Niit, Ellen, Paldre, Leho, Sak, Kristi, Veismann, Ann 1997. Kihnu murde assimileerumise mustreid Manilaiul. Pühendusteos Huno Rätsepale 28.12.1997. (Tartu Ülikooli eesti keele õppetooli toimetised 7.) Toim Mati Erelt, Meeli Sedrik, Ellen Uuspõld. Tartu: Tartu Ülikooli Kirjastus, lk 26-44.

Harrington, Jonathan, C a s sidy, Stephen 1994. Dynamic and target theories of vowel classification: Evidence from monophthongs and diphthongs in Australian English. - Language and Speech, kd 37, nr 4, lk 357-373.

Holbrook, Anthony, Fairbanks, Grant 1962. Diphthong formants and their movements. - Journal of Speech, Language and Hearing Research, kd 5, nr 1, lk 38-58.

Jacewicz, Ewa, Fox, Robert A., S almons, Joseph 2011. Vowel change across three age groups of speakers in three regional varieties of American English. Journal of Phonetics, kd 39, nr 4, lk 683-693.

L a d e foged, Peter 2006. A Course in Phonetics. Boston: Wadsworth Publishing. 
Lehiste, Ilse 1970. Diphthongs versus vowel sequences in Estonian. - Sixth International Congress of Phonetic Sciences, Prague, Czech, 7-13 September 1967, Proceedings. Prague: Hueber, lk 539-544.

Lip pus, Pärtel, As u, Eva Liina, Teras, Pire, Tuisk, Tuuli 2013. Quantity-related variation of duration, pitch and vowel quality in spontaneous Estonian.Journal of Phonetics, kd 41, nr 1, lk 17-28.

L o n n, Varje, Niit, Ellen 2002. Saarte murde iseloomustus ja liigendus. - Saarte murde tekstid. Eesti murded VII. Toim Evi Juhkam. Tallinn: Eesti Keele Instituut, lk 11-64.

M cD ou gall, Kirsty 2006. Dynamic features of speech and the characterisation of speakers: Towards a new approach using formant frequencies. - The International Journal of Speech, Language and the Law, kd 13, nr 1, lk 89-126.

McDougall, Kirsty, Nolan, Francis 2007. Discrimination of speakers using the formant dynamics of /u:/ in British English. - 16th International Congress of Phonetic Sciences, Saarbrücken, Germany, 6-10 August, Proceedings. Toim Jürgen Trouvain, William J. Barry. Saarbrücken: Universität des Saarlandes, lk 1825-1828.

Pajusalu, Karl, Hennoste, Tiit, Niit, Ellen, Päll, Peeter, Viikberg, Jüri 2009. Eesti murded ja kohanimed. Toim Tiit Hennoste. Tallinn: Eesti Keele Sihtasutus.

Pi ir, Hille 1985. Acoustics of the Estonian diphthongs. - Estonian Papers in Phonetics 1982-1983. Tallinn, lk 5-103.

R Core Team 2013. R: A language and environment for statistical computing. R Foundation for Statistical Computing, Vienna, Austria. http://www.R-project. org/

S a a r, Theodor 1958. Kihnu murde häälikud. Käsikiri Eesti Keele Instituudi eesti murrete ja soome-ugri keelte arhiivis (KT170).

S a a r, Theodor, V a l m et, Aino 1997. Kihnu murrakust. - Vana kannel VII:1. Kihnu regilaulud. Koost ja toim Ottilie Kõiva, Ingrid Rüütel. Tallinn: Eesti Kirjandusmuuseum, Eesti Rahvaluule Arhiiv, Eesti Keele Instituut, folkloristika osakond, lk 35-40.

Sa a reste, Andrus 1920. Häälikajalooline uurimus Kihnu murdest. Konsonandid. Käsikiri Tartu Ülikooli Eesti murrete ja sugulaskeelte arhiivis (H0098).

S a n g, Joel 2009. Ühest fonotaktilisest kollisioonist (Kihnu näitel). - Keel ja Kirjandus, nr 11, lk 809-817.

Ter a s, Pire 1996. Eesti keele teise silbi diftongide akustikast. Tartu. Diplomitöö. Käsikiri Tartu Ülikooli eesti keele osakonnas.

Te r a s, Pire 2012. Eesti diftongid spontaankõnes. - Emakeele Seltsi aastaraamat, nr 57. Tallinn: Teaduste Akadeemia Kirjastus, lk 235-248.

Türk, Helen 2013. Kihnu murraku diftongidest. Tartu. Magistritöö. Käsikiri Tartu Ülikooli eesti keele osakonnas. http://dspace.utlib.ee/dspace/bitstream/handle/10062/30847/Turk_Helen_MA2013.pdf

Vi it s o, Tiit-Rein 2008. Liivi keel ja läänemeresoome keelemaastikud. Tartu-Tallinn: Eesti Keele Sihtasutus.

Watson, Catherine I., Harrington, Jonathan 1999. Dynamic English vowel formants. - Journal of the Acoustical Society of America, kd 106, nr 1, lk 458468.

Wiik, Kalevi 1965. Finnish and English Vowels. - Annales Universitatis Turkuensis, Series B 94. Turku: Turun yliopisto. 


\section{Diphthongs and triphthongs in the Kihnu variety of Estonian}

Keywords: phonetics, diphthongs, triphthongs, Kihnu vocalic system

The main focus of the current study is on the investigation of component durations in diphthongs in the second (Q2) and third (Q3) quantity degree. Additionally, temporal patterns of triphthongs as well as the quality of monophthongs, diphthongs and triphthongs is studied. The analysis is based on read materials from 13 speakers of the Kihnu variety of Estonian. Application of the method of formant dynamics enables to follow the change in vowel quality throughout the whole vowel. While monophthongs have short trajectories, indicating that the vowel quality stays roughly the same around the target, the trajectories of diphthongs are longer connecting the two target vowels. The formant trajectories of triphthongs are the longest. It is shown that compared to long vowels short vowels in Kihnu are more centralised, which is also the case in Standard Estonian. Long monophthongs in Q2 and Q3 do not differ in quality. The results on temporal characteristics are in line with findings from Standard Estonian: long monophthongs and diphthongs are of similar length, both being longer in Q3. It was found that the first diphthong component is always shorter than the second one, and that both diphthong components are longer in Q3 than in Q2. These findings support earlier observations by Ilse Lehiste (1970). In triphthongs, the first and the second components are of more or less equal duration being considerably shorter than the third component which comprises on average $44 \%$ of the total duration of the triphthong.

Helen Türk (b. 1987), MA, University of Tartu, Institute of Estonian and General Linguistics, PhD Student, helen.tyrk@gmail.com

Eva Liina Asu (b. 1971), PhD, University of Tartu, Institute of Estonian and GeneralLinguistics, Senior Researcher,eva-liina.asu@ut.ee

Pärtel Lippus (b. 1980), PhD, University of Tartu, Institute of Estonian and General Linguistics, Researcher, partel.lippus@ut.ee

Ellen Niit (b. 1944), PhD, University of Tartu, Institute of Estonian and General Linguistics, Researcher, elniit@ut.ee 